Jadwiga Charzyńska

Centrum Sztuki Współczesnej Łaźnia Gdańsk

\title{
Chimera i wirtualna sieć, czyli przyczynek do nowego porządku świata (o związkach sztuki i nauki na przykładzie projektu "Art + Science Meeting")
}

\section{Co oznacza termin "sztuka plus nauka” z perspektywy programowej Centrum Sztuki Współczesnej Łaźnia?}

Sprawa nie jest prosta. Nowe technologie, czyli owoc naukowego wysiłku, to część naszej codzienności cierpiącej wręcz na ich nadmiar. Sztuka zaś jest papierkiem lakmusowym, zwierciadłem i interpretacją otaczającego nas świata - również jego technologicznego rozwoju.

Podejmując się zadania organizacji pokazów sztuki łączącej w sobie kreację artystyczną z naukową, jesteśmy zobowiązani do wzięcia pod uwagę tego, co motywuje to działanie. Artyści, zastanawiając się nad skutkami wprowadzanych zmian społecznych, które są spowodowane stosowaniem coraz nowszych technologii, zgłębiając tę kwestię przy pomocy plastycznych środków, edukują także odbiorcę - często z przymrużeniem oka, bo przestrzeń galerii dopuszcza fantazję. Należy także pamiętać, że „w tych «technologicznie określonych» poszukiwaniach chodzi w równej mierze o próbę wyjaśnienia złożoności relacji społecznych, dążenie do precyzyjnego opisu rzeczywistości oraz stawianie wciąż nowych pytań, które pomogłyby nadążyć kulturowej refleksji za kulturową dynamiką" (Zabicki 2007: 20). Wedle Jeana Baudrillarda "nowe technologie nie wyobcowują jednostki, one tworzą z nią zintegrowany obwód” (za: Żabicki 2007: 24). Ogromne wrażenie robi tu także liczba dzieł interaktywnych, angażujących nas na wiele sposobów, w których nie widać końca przekraczania granic i poszerzania integracji naszego ciała z maszynerią. Gdy obserwujemy eksperymenty Stelarca, zastanawiamy się, czy Superman lub Spiderman nadal przynależą do świata fantazji. Dokąd to poszukiwanie poszerzania ludzkich możliwości nas prowadzi?

Kwestia refleksji jest trudnym zagadnieniem w kontekście współczesnej tendencji podawania wszelkiej wiedzy w „opakowaniach” wymyślonych przez marketing i różnej proweniencji promotorów, aby zachęcić odbiorcę do sięgnięcia po ten, a nie inny "produkt”. Przez termin "opakowanie” rozumiem schematyczne i często powierzchowne, rozczarowujące przedstawienie zagadnienia. Mam wrażenie, że nastał wyścig w podawaniu wszystkiego w jak najładniejszej formie i zawartość staje się czasem sprawą drugorzędną. Sztuka posługuje się w przekazie 
"obrazem", dbając o zachowanie równowagi pomiędzy kwestiami estetycznymi i formalnymi, doskonale demaskuje przypadki "pustych opakowań".

Obecnie artyści coraz więcej uwagi poświęcają naukowym poszukiwaniom i dokonaniom. Chociaż fascynacja techniką i technologią towarzyszy sztuce od zawsze, to od przełomowej wystawy „Cybernetic Serendipity"1 , której kuratorem była Jasia Reichardt, twórczość na styku sztuki i nauki zaczęła gościć coraz częściej $w$ galeriach i muzeach w Europie i na świecie.

Centrum Sztuki Współczesnej Łaźnia jest jedną z pierwszych galerii w Polsce podejmujących ten temat w projekcie "Art + Science Meeting" zainicjowanym w 2011 roku i zaplanowanym jako wieloletnie przedsięwzięcie. Jego koncepcja rodziła się kilka lat i ostatecznie, gdy Gdańsk zdecydował się aplikować o tytuł Europejskiej Stolicy Kultury, wspólnie z profesorem Ryszardem Waldemarem Kluszczyńskim wypracowaliśmy jej ostateczną formę. Każde z nas opisało swoje przemyślenia. W swoim wprowadzeniu zastanawiam się nad tym,

Jak odnaleźć się w świecie zniewolonym nadmiarem informacji? Czy można bronić się przed wszechobecnymi manipulacjami serwowanymi wszędzie i na wszelkie dostępne sposoby: od agresywnej reklamy po oddziaływanie na podświadomość. Może jesteśmy w stanie pokonać naszą słabość: skłonność do destrukcji, może potrafimy stworzyć lepszy świat? Dążenie do ideału bywa zgubne, zwłaszcza gdy ambicja tłumi empatię.

Artyści stanowią tę „uwrażliwioną" grupę społeczną, która podejmuje wszystkie ważne dla naszej cywilizacji tematy. Nie obawiają się dotykać spraw jeszcze do końca niezbadanych. Poprzez swoją twórczość stawiają pytania, na które nauka wymagająca twardego dowodu - nie ma jeszcze odpowiedzi. Sztuka pozwala pytać, zanim nawet powstanie właściwy język, by udzielić odpowiedzi. Strategie artystyczne, cały proces twórczy na każdym etapie może być ujawniany, jeśli artysta uzna, że eksponowanie twórczego procesu jest istotne w podjętym działaniu. [...] Dotykając zagadnień nowych metod komunikacji, stosowania sztuk wizualnych do ilustrowania, badania czy opisywania zagadnień z zakresu nauk ścisłych, pokazujemy też odbiorcy techniczne rozwiązania, które z czasem trafiły lub wkrótce trafią na rynek, wpiszą się w codzienność jak wiele wynalazków, jeszcze ledwie kilka dziesięcioleci zupełnie nieznanych, lecz dziś niezbędnych $\mathrm{w}$ normalnym funkcjonowaniu współczesnego świata. Podejmując kwestie często dotykające obwiązujących norm etycznych i obyczajowych, poprzez rozważania prowadzone $\mathrm{w}$ ramach projektu artystycznego, mamy nadzieję umożliwić publiczności zmierzenie się z jej wątpliwościami poprzez sztukę (Charzyńska 2011).

Profesor Kluszczyński ze swej perspektywy tak wyjaśnia nasze działania:

Obserwowane współcześnie transformacje twórczości artystycznej, jej wielokierunkowe hybrydyzacje, coraz wyraźniej kierują ją, między innymi, w stronę rozległego obszaru badań naukowych, zarówno ku naukom humanistycznym i społecznym, jak i w stronę dyscyplin określanych mianem nauk ścisłych. We współczesnym świecie prym wiodą tendencje o charakterze wielodyscyplinarnym i transgranicznym. Progresywna sztuka podejmuje dziś zadania badań kulturowych, wpisując się przy tym

1 Wystawa została przygotowana w londyńskim Instytucie Sztuki Współczesnej (ICA) w 1968 roku i jest jedną z dwu wystaw po raz pierwszy dokumentujących spotkanie sztuki i nowoczesnej technologii. Tą drugą wystawą była „The Machine as Seen at the End of the Mechanical Age" przygotowana przez Pontusa Hulténa w nowojorskim Museum of Modern Art (MoMa). 


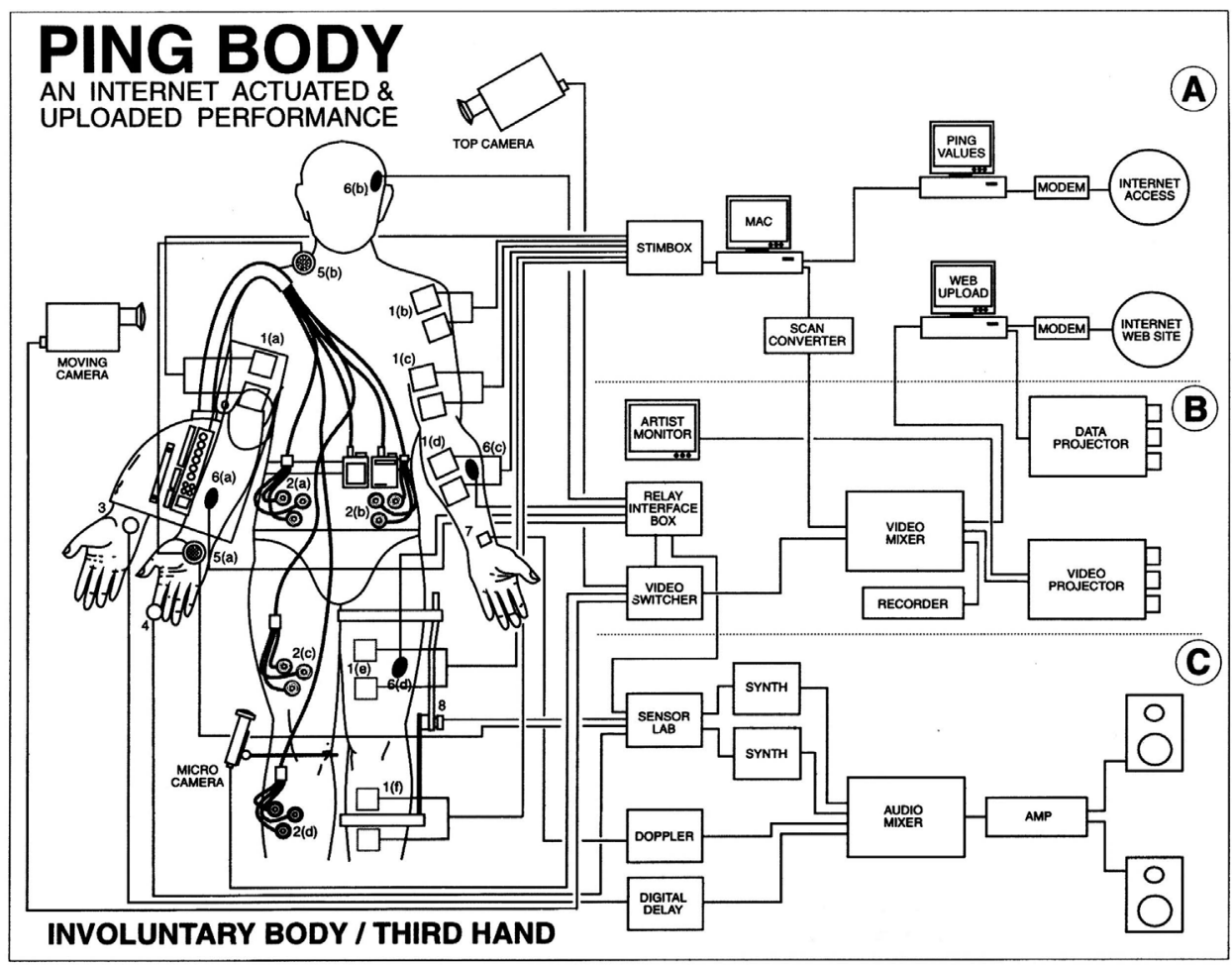

Il. 1. Schemat Involuntary Body/Third Hand. Fot. z arch. Stelarca

zwykle w nurt teorii krytycznej, jak również dialoguje twórczo z biotechnologią, genetyką, informatyką, nanotechnologią, badaniami nad sztucznym życiem i sztuczną inteligencją, a także z licznymi dyscyplinami inżynierskimi (Kluszczyński 2011a).

Pionierskie działania Franka Maliny czy Györgya Kepesa są kontynuowane przez wielu artystów. Należy do nich duet: Monika Fleischmann i Wolfgang Strauss. Tak się złożyło, że ich twórczość zaprezentowaliśmy w Gdańsku w 2011 roku. Wystawa „Pleasure of Light”2 przedstawiała kinetyczne eksperymenty w formie obrazów lub instalacji świetlnych autorstwa Franka Maliny oraz Györgya Kepesa. Natomiast w „Perfoming data” Monika Fleischmann i Wolfgang Strauss mierzyli się z nowoczesnymi technologiami w kontekście komunikacji i archiwizacji danych. Twórcy tacy jak: Eduardo Kac, Oron Catts czy Guy Ben-Ary, swoją współpracę z laboratoriami zajmującymi się biotechnologią i medycyną wiążą z badaniami nad sieciami neuronowymi, kodami genetycznymi czy szeregiem eksperymentów ze strukturami komórkowymi. Podobnie jak Christa Sommerer i Laurent Mignonneau ${ }^{3}$ także chętnie posługują się narzędziami

\footnotetext{
${ }^{2}$ Więcej na ten temat $\mathrm{w}$ publikacji pod tym samym tytułem wydanej przy okazji pokazu wystawy przeniesionej do Gdańska z Ludwig Múzeum w Budapeszcie na www.laznia.pl [dostęp: 30.04.2013] w archiwum wystaw oraz na http://artandsciencemeeting.pl/ [dostęp: 30.04.2013].

${ }^{3}$ Dorobek tego duetu pokazaliśmy w wystawie „Wonderful Life” oraz w publikacji przygotowanej w CSW Łaźnia w 2012 roku w ramach "Art + Science Meeting”.
} 
pozwalającymi wymyślać wirtualną rzeczywistość. Stelarc ${ }^{4}$, Bill Vorn ${ }^{5}$ oraz Ken Feingold ${ }^{6}$ poszerzają język sztuki o rozwiązania inżynierskie i interaktywne roboty. Należy zwrócić uwagę na różnice pomiędzy nimi - szczególnie na Stelarca eksperymentującego z ludzkim ciałem (własnym) i poszerzaniem jego możliwości poprzez dodawanie mu mechanicznych ramion, dłoni czy innych urządzeń przedłużających bądź wzmacniających kończyny, a nawet całe ciało. Najgłośniejszym eksperymentem związanym z potrzebą przekraczania granic ludzkich możliwości jest performance australijskiego artysty, w którym wisi na hakach wczepionych w skórę. Strategia Stelarca dotyczy pytania o "ja" i podmiotowy wymiar człowieka. W tych przedsięwzięciach artystyczna kreacja jest łączona z odkryciami czy wynalazkami.

Po informatyczne narzędzia sięgają niemal wszyscy wspomniani twórcy. Jednakże jednym z ciekawszych eksperymentów, jaki utkwił mi w pamięci, to „Telematic Encounter" powstały w 1996 roku - dzieło Paula Sermona ${ }^{7}$, którego twórczość jest określana mianem sztuki telematycznej. Jego wirtualne postaci, awatary rozmawiające w czasie rzeczywistym z ludźmi, wprawiają w zdumienie. A to jest rola sztuki i takie credo towarzyszy Damienowi Hirstowi wprowadzającemu filozoficzny dyskurs w cykl „Art + Science Meeting” poprzez zestaw prac zebranych pod tytułem „Nowa Religia”" . Wystawa Hirsta ma charakter krytyczny, typowy dla sztuki zaangażowanej, zaliczanej do nurtu postmodernistycznego. Dzieła te nie są efektem pracy z biologiem czy chemikiem, lecz spojrzeniem na kondycję współczesnego świata z perspektywy określonej warunkami społecznymi i kulturowymi, w jakich funkcjonuje twórca.

Szeroko rozumiana fantazja jest myślą przewodnią koncepcji wystawy zatytułowanej „Nearly Human” autorstwa Jasi Reichardt ${ }^{9}$. Równie ważne są tam przemysłowe roboty Richarda Krieschego ${ }^{10}$, jak i wciąż robiący swój portret muł Tima Lewisa $^{11}$. A każdy z nich odnosi się do innej ludzkiej potrzeby.

\section{Społeczny aspekt zjawiska}

Niepostrzeżenie konsumpcyjna filozofia marketingowców i sprzedawców dóbr wszelakich zdominowała współczesny, znany nam świat. Potrzeba posiadania coraz większej liczby rzeczy i ich coraz nowszych modeli, podsycana akcjami reklamowymi, przekroczyła Rubikon. Skupianie się jednostki na sobie, czynienie swego życia coraz wygodniejszym nie jest niczym nagannym (wszak ten

\footnotetext{
${ }^{4}$ Więcej na temat twórczości Stelarca na http://stelarc.org/?catID =20247 [dostęp: 30.04.2013].

${ }^{5}$ Więcej na temat twórczości Billa Vorna na http://billvorn.concordia.ca/menuall.html [dostęp: 30.04.2013].

${ }^{6}$ Więcej na temat twórczości Kena Feingolda na http://www.kenfeingold.com/ [dostęp: 30.04.2013].

${ }^{7}$ Więcej na temat tego artysty na http://www.paulsermon.org/ [dostęp: 30.04.2013].

${ }^{8}$ Wystawa została zaplanowana na 2015 rok w CSW Łaźnia w ramach „Art + Science Meeting".

${ }^{9}$ Wystawa została zaplanowana na 2015 rok w CSW Łaźnia w ramach "Art + Science Meeting".

${ }^{10}$ Praca zatytułowana Model świata po raz pierwszy została pokazana w 1986 roku na Biennale w Wenecji.

${ }^{11}$ Więcej na temat twórczości Tima Lewisa na http://www.flowersgallery.com/artists/view/timlewis [dostęp: 30.09.2014].
} 


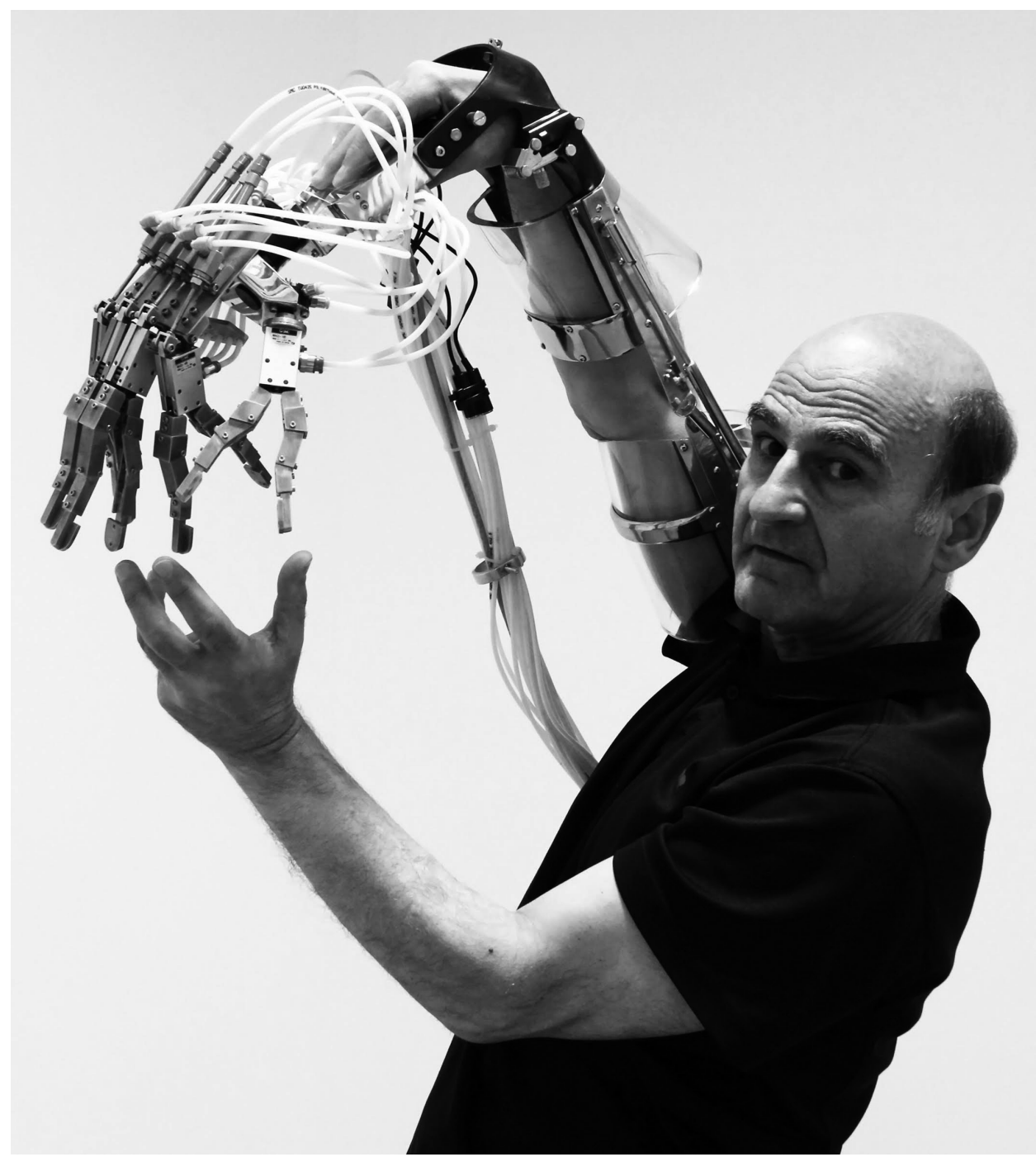

Il. 2. Stelarc prezentuje Extended Arm - Melbourne, Hamburg 2000 r.

Fot. Dean Winter, $\mathrm{z}$ arch. Stelarca

mechanizm zapewnił ciągłość gatunku), jeśli ten egoizm nie sieje spustoszenia w innym miejscu i nie narusza równowagi. Świat jest zbiorem naczyń połączonych, gdzie nic nie jest stałe. W odniesieniu do "pożerającego" nas konsumpcjonizmu rodzi się smutna konstatacja: zapominamy, że „celem naszego życia nie powinno być posiadanie bogactw, lecz bogactwo bycia” (Fromm 2009: 30), jak pisał Erich Fromm. Gdy rozejrzymy się dookoła, jego pytanie „mieć czy być?” okaże się niezwykle aktualne. Każdy ze wspomnianych twórców podejmuje tę kwestię, bo jedną z ról artystów jest reagowanie na zjawiska, które są istotne dla przyszłości, wyraziste demonstrowanie poglądów z nadzieją bycia usłyszanym. 
Sztuka jest narzędziem filozoficznym. Artysta plastyk filozofuje poprzez użycie technik typowych dla swojej dyscypliny, opowiada, malując, rysując, rzeźbiąc, fotografując czy organizując akcje artystyczne. W minionych epokach na język sztuki składały się techniki malarskie, rysunkowe i rzeźbiarskie. Ostatnie stulecie eksplodowało rozwojem technologii - malarze zyskali gotowe farby i inne materiały plastyczne, ale też aparaty fotograficzne, kamery i komputery. Informatyka, telewizja, radio i Internet zrewolucjonizowały porządek społeczny, a sztuka jest wyrazem tych przemian. Fantazja ludzka, zdobywszy morza i oceany, zagląda do wnętrza komórek i atomów dzięki supermikroskopom, a fotografia wizualizuje te odkrycia. Zobaczyliśmy niewidzialne. Nasza ciekawość penetruje kosmos przy pomocy potężnych teleskopów i sond, ale już eksperymenty w Wielkim Zderzaczu Hadronów, mające na celu odkrycie tajemnicy powstania wszechświata, wzbudzają tyleż samo zaciekawienia, co niepokoju.

Układany przez stulecia porządek społeczny w Europie, zbudowany wedle reguł chrześcijańskich i demokratycznych, zaczyna się chwiać pod wpływem wydarzeń $w$ regionie Morza Śródziemnego. Nie wiemy jeszcze, jak dalece rozleje się narastająca agresja. Postęp technologiczny może być pomocny w opanowaniu trudnej sytuacji, lecz te same narzędzia mogą przyczynić się do katastrofy. Tempo przepływu informacji, jakie zapewnia Internet, pozwala bardzo sprawnie rozsyłać wiadomości, ale też nimi manipulować. Drogą radiową można sterować urządzeniami na odległość. Jaką twarz ma współczesny Frankenstein? Czy raczej mówimy już o wielogłowej chimerze? Lęk, jaki wzbudzają serwowane codziennie wieści, może motywować do pozytywnego działania lub obudzić bestię. O tych obawach mówi „Nowa Religia” oraz eksperymenty Stelarca i Kena Feingolda.

Artyści zwracają również uwagę na to, co robimy z przyrodą. Wystawa "Crude Life" przygotowana przez Orona Cattsa i Ionat Zurr ${ }^{12}$ dotyczy kwestii eksperymentowania z tkanką organiczną. Czy możemy wyhodować kotlet z komórki bez konieczności pozbawienia życia innego stworzenia? Jak ma się do tego łańcuch pokarmowy rządzący gatunkami i całą przyrodą?

Guy Ben-Ary wraz z zespołem naukowców bada tajemnice mózgu i możliwości rekonstrukcji połączeń nerwowych. Czy ciało ludzkie można wyposażyć $\mathrm{w}$ dodatkowe ramiona, dłonie i uczynić je niemal niezniszczalnym? Eksplorowaniu tych tajemnic poświęcił się Stelarc. Pokazane na wystawie "Mięso, Metal i Kod: Rozchwiane Chimery"13 eksperymenty artysty dają obraz ludzkiej potrzeby przekraczania granic.

Sztuczne życie, „taśma życia” odtwarzana w nowych technologiach jako zbiór informacji inspiruje Christę Sommerer i Laurenta Mignonneau ${ }^{14}$, którzy od dwóch dekad opracowują interfejsy, interaktywne urządzenia symulujące procesy ewolucyjne i zachowania żywych organizmów poprzez tworzenie komputerowych

${ }^{12}$ Więcej na temat twórczości duetu w publikacji wydanej przez CSW Łaźnia towarzyszącej wystawie "Crude Life" opisanej na www.laznia.pl, http://artandsciencemeeting.pl/?page_id=485 oraz na http://www.ibmc.up.pt/hybrid/content.php?menu=6\&submenu=59, http://www.tca.uwa. edu.au/ [dostęp: 30.04.2013].

${ }^{13}$ Więcej o twórczości artysty i wystawie "Mięso, Metal i Kod: Rozchwiane Chimery” można znaleźć w publikacji pod tym samym tytułem wydanym przez CSW Łaźnia w 2014 roku oraz na http://laznia.pl/aktualnosciart,822,2014_mieso_metal_i_kod_rozchwiane_chimery.html [dostęp: 30.08.2014].

${ }^{14}$ Więcej na stronie tego duetu: http://www.interface.ufg.ac.at/christa-laurent [dostęp: 30.08.2014]. 


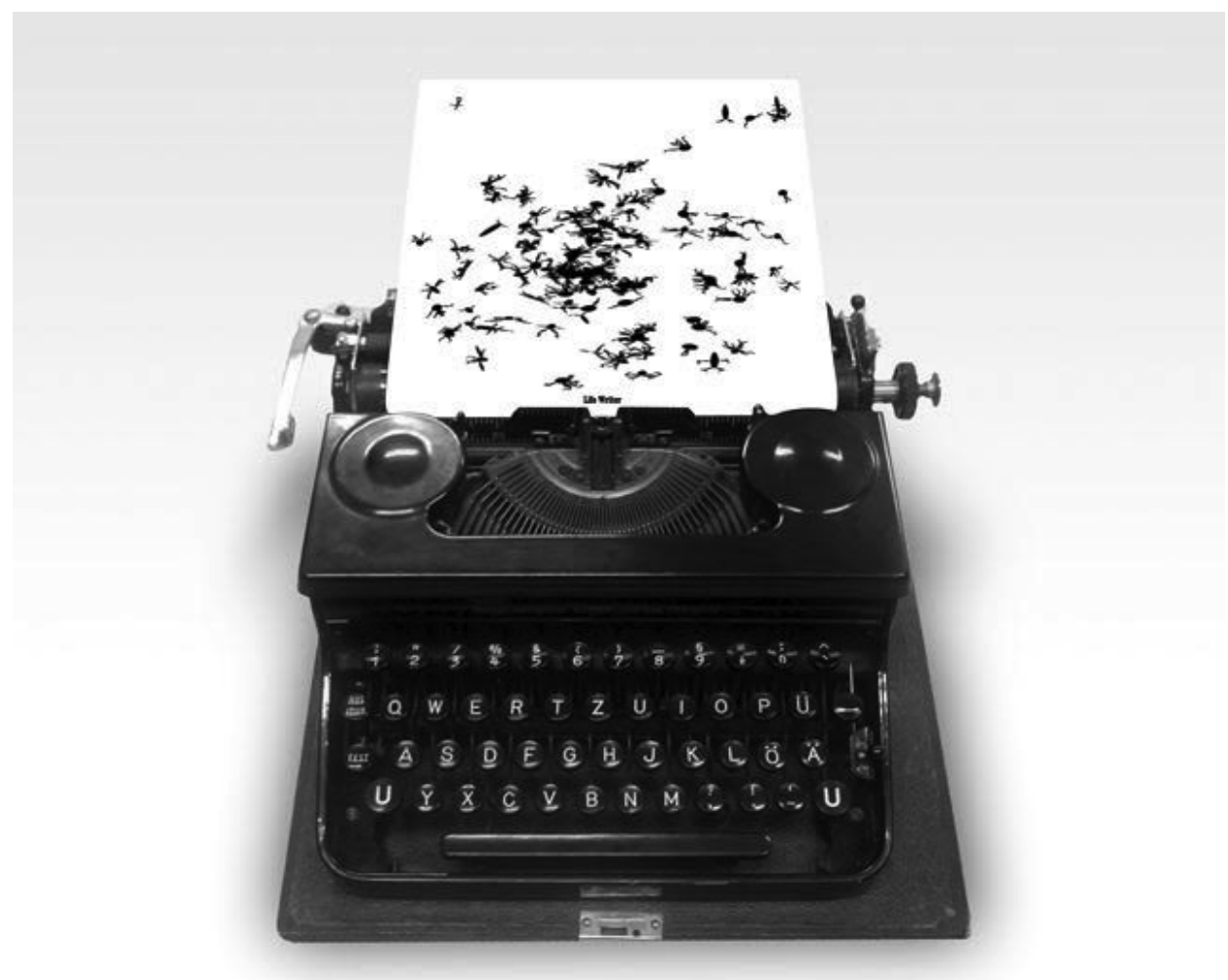

Il. 3. Life Writer, 2006, Christa Sommerer \& Laurent Mignonneau.

Fot. $\mathrm{z}$ arch. Christy Sommerer i Laurenta Mignonneau

algorytmów. Jest to przykład, jak nowe technologie adaptują stare, i to działanie wpisuje się w długą historię urządzeń naukowych. Temu zagadnieniu była poświęcona wystawa „Wonderful Life” ${ }^{\prime 15}$ zrealizowana w 2012 roku w Łaźni. Słynny króliczek GFP Eduarda Kaca ${ }^{16}$ był pionierskim działaniem eksperymentującym z DNA i zapoczątkował kierunek w sztuce określany jako Bio Art. Jego projekt „Lagoglyphs” nawiązujący do wyżej wspominanego królika został pokazany w Gdańsku w 2009 roku' ${ }^{17}$.

\section{Spostrzeżenia i uwagi podsumowujące w kontekście unikatowości projektu CSW Łaźnia}

Konsekwentnie kolejni twórcy i teoretycy starają się zrozumieć i objaśnić złożoność współczesnej cywilizacji naszpikowanej technicznymi rozwiązaniami

${ }^{15}$ Więcej na ten temat $\mathrm{w}$ publikacji wydanej przez CSW Łaźnia pod tym samym tytułem i w archiwum wystaw na www.laznia.pl oraz http://artandsciencemeeting.pl/ [dostęp: 30.04.2013].

${ }^{16}$ Więcej informacji na http://www.ekac.org/transgenicindex.html [dostęp: 30.04.2013].

17 Więcej na http://laznia.pl/aktualnosciart,738,2009_eduardo_kac_lagoglyphs.html [dostęp: 30.04.2013]. 
mającymi poprawić jakość życia. Sięgają po schematy kulturowe, lokalne tradycje i globalne zagadnienia. Jednocześnie wciąż zwracają uwagę na to, że współczesny świat jest pełen kontrastów: są miejsca, gdzie ludzie zupełnie stracili kontakt $\mathrm{z}$ naturą i regiony, gdzie natura trzyma ich $\mathrm{w}$ ryzach. Z krótkiej perspektywy losu pojedynczego człowieka nie zawsze zdołamy dostrzec rezultaty działania sił przyrody, ich aktywność i potęgę, gdyż te ujawnią się po stuleciach i epokach.

$\mathrm{W}$ regionach świata postrzeganych jako zamożne, w których pieniądz jest miarą sukcesu, konsumpcyjny styl życia spycha duchowość na dalszy plan. Potrzeba uporządkowania i zrozumienia naszego otoczenia oraz towarzyszący temu pragmatyzm zderzają się z ludzkimi wyobrażeniami „lepszego" życia czy czyhających zagrożeń. Człowiek z natury rzeczy obawia się zmian, poczucie bezpieczeństwa buduje na stabilności, a współczesne tempo przemian jest zawrotne. Dotyczy to wszelkich dziedzin życia i obejmuje niemal cały świat. Wynalezienie żarówki i elektryczności sprawiło, że przestaliśmy podporządkowywać swoje życie porom dnia, samoloty spowodowały, że w kilka godzin możemy znaleźć się w dowolnym miejscu na świecie, natomiast Internet i połączenia satelitarne umożliwiły wymianę informacji, komunikację $\mathrm{w}$ czasie rzeczywistym z dowolnym punktem na globie bez opuszczania pokoju, w którym pracujemy, oczywiście pod warunkiem, że jesteśmy w posiadaniu urządzenia podłączonego do sieci. Łatwość $w$ przesyłaniu i udostępnianiu wiadomości spowodowała ogromne zamieszanie związane $\mathrm{z}$ weryfikacją i porządkowaniem zgromadzanego materiału w wirtualnej przestrzeni. Archiwizacja danych stała się wyzwaniem dla archiwistów i informatyków. Nowego wymiaru nabrała sprawa praw autorskich. Jednocześnie zaczęliśmy zastanawiać się nad potrzebą refleksji, coraz większy bowiem pośpiech i rosnący apetyt na wszystko oraz brak czasu na zdystansowanie się skracają perspektywę widzenia.

Bardzo ważnym odniesieniem jest zwrócenie uwagi na zjawisko samoistnego izolowania się środowisk, co szczególnie widać pomiędzy humanistami i przedstawicielami nauk ścisłych. W trakcie konferencji zorganizowanej w roku 2011, zatytułowanej „W stronę trzeciej kultury. Koegzystencja sztuki, nauki i technologii" i podsumowanej w publikacji pod tym samym tytułem (Kluszczyński 2011b), odwoływano się do tekstu Dwie kultury Charlesa Percy'ego Snowa oraz do dokonań takich ludzi jak Frank Malina. Jest to postać ogromnie ważna przede wszystkim przez fakt utworzenia w roku 1968 platformy wymiany doświadczeń i poglądów dla środowisk twórczych, czyli pisma „Leonardo"18, które mimo różnych perypetii wychodzi do dziś. Obecnie jest poszerzone o wersję internetową i szereg komplementarnych przedsięwzięć.

Gdańskiej konferencji towarzyszyły wystawy trzech artystów. Obok tej wspominanego Franka Maliny, pokazanej w zestawieniu z Györgym Kepesem na wystawie "The Pleasure of Light" ${ }^{19}$, kwestię roli technologii we współczesnym świecie zaprezentowali Monika Fleischmann i Wolfgang Strauss w odsłonie zatytułowanej „Performing Data” (zob. Kluszczyński 2011c). Jednym z istotnych wątków ekspozycji była sprawa archiwizacji i dystrybucji danych coraz chętniej gromadzonych $\mathrm{w}$ formie elektronicznej. Badacze i artyści podjęli również kwestię

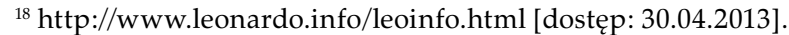

${ }^{19}$ Więcej na stronie www.laznia.pl oraz w The pleasure of light. György Kepes, Frank J. Malina (Czeglédy-Nagi 2011).
} 


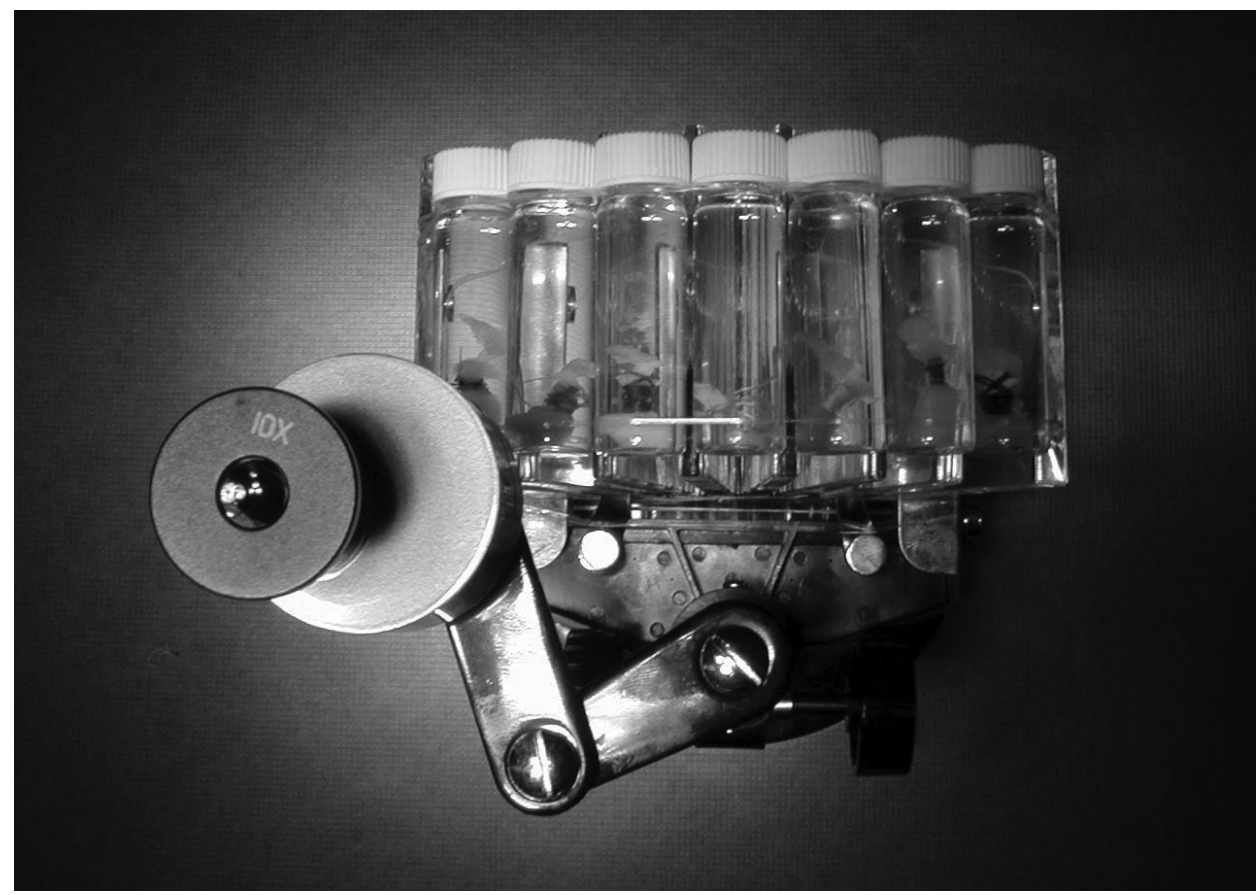

Il. 4. Semi-Living Dolls Display, "The Tissue Culture and Art Project”.

Fot. $\mathrm{z}$ arch. Orona Cattsa i Ionat Zurr

narzędzi służących budowie tych archiwów oraz umożliwiających ich przeszukiwanie i wykorzystywanie w szeroko rozumianej edukacji. Jednakże komputery, oprogramowanie i wszelkiego rodzaju maszyny wpisują się w świat organiczny ludzi, zwierząt i roślin. Poszukiwania wokół zjawisk, gdzie technika spotyka się z biologią, to wczesne interaktywne realizacje Christy Sommerer i Laurenta Mignonneau oraz szereg przedsięwzięć Eduardo Kaca ${ }^{20}$, który pojawił się w gdańskiej Łaźni w 2009 roku ${ }^{21}$, wzbudzając emocje opowieściami o swych pracach w dziedzinie genetyki. Szczególnie kontrowersyjny był eksperyment ze wspomnianym już króliczkiem, którego kod genetyczny został zmodyfikowany na etapie zygoty. Natomiast w roku 2011 Victoria Vesna ${ }^{22}$ w duecie z chemikiem i nanotechnologiem Jamesem Gimzewskim ${ }^{23}$ zaprezentowali instalację „Blue Morph"24, która nawiązywała do badań prowadzonych nad gatunkiem motyla o tej samej nazwie. Rok później swoją twórczość bazującą na biotechnologii pokazali Oron Catts i Ionat Zurr. Przedsięwzięcie zatytułowane "Crude Life" zapoczątkowało współpracę CSW Łaźnia z Międzyuczelnianym Wydziałem Biotechnologii Uniwersytetu Gdańskiego i Uniwersytetu Medycznego w Gdańsku. Przygotowania

${ }^{20}$ http://www.ekac.org/ [dostęp: 20.04.2013].

${ }^{21}$ Więcej o przyjeździe artysty do Gdańska na http://laznia.pl/edukacjaart,288,2009_immediate_ art_eduardo_kac_transformacja_zycia_mutacja_sztuki_html.

${ }^{22}$ http://victoriavesna.com/ [dostęp: 30.04.2013].

${ }^{23}$ http://gim.chem.ucla.edu/ [dostęp: 30.04.2013].

${ }^{24}$ Wystawa „Blue Morph” została przygotowana przez Nadbałtyckie Centrum Kultury w 2011 roku w ramach „Art + Science Meeting”. O swoim projekcie Victoria Vesna pisze w tekście dostępnym na http://artandsciencemeeting.pl/?page_id=408 [dostęp: 30.04.2013]. 


\section{The Process of Giving Birth to}

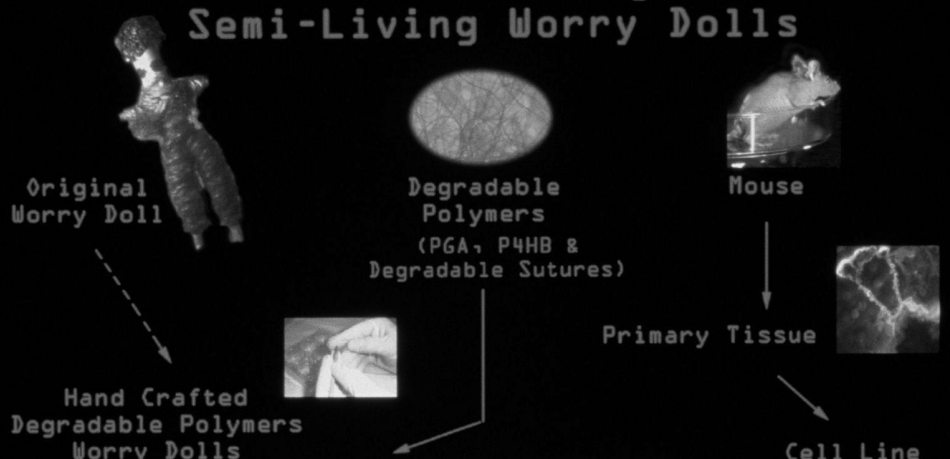

Degradable Polymers

Worry Dolls

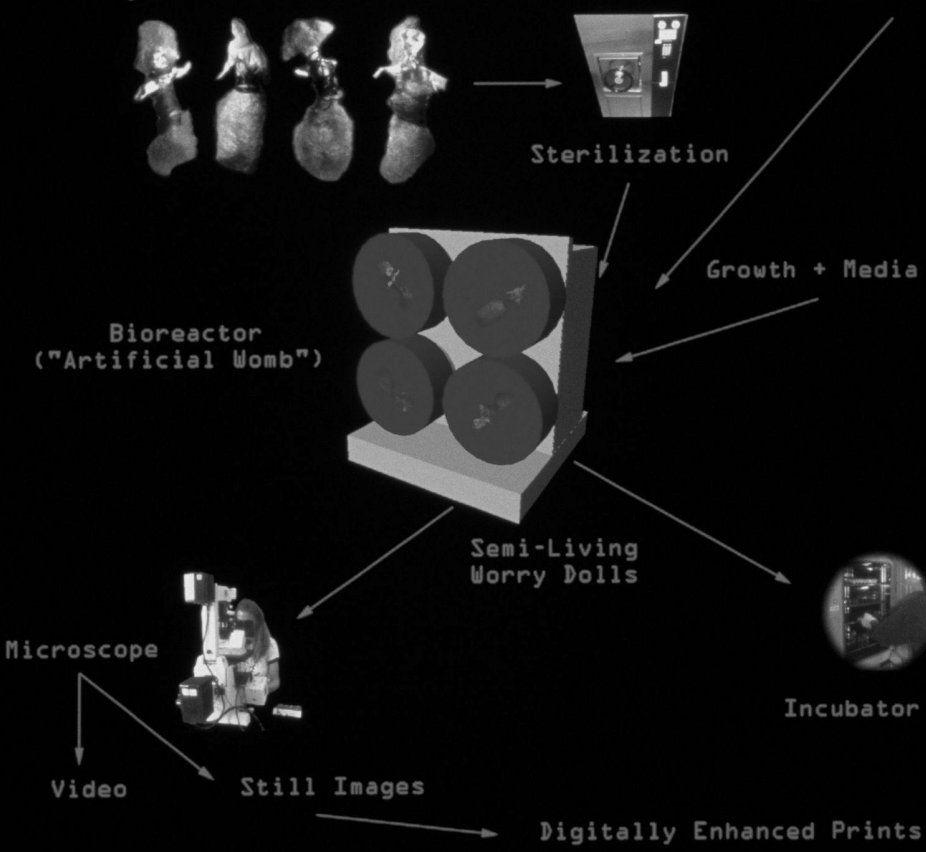

Cel1 Line

Il. 5. Schemat procesu powstawania Semi-Living Dolls.

Fot. $\mathrm{z}$ arch. Orona Cattsa i Ionat Zurr

do wystawy rozpoczęły się w laboratoriach uniwersyteckich, a później - dzięki zaangażowaniu ich pracowników - rozwijały się zgodnie z koncepcją autorów.

Inne punkty widzenia relacji człowiek-maszyna pokazali Stelarc, Ken Feingold i Bill Vorn. Stelarc zdecydowanie opowiada się za koncepcją symbiozy pierwiastka biologicznego i technologicznego, połączenia mięsa i metalu. Miniatury urządzeń, nanotechnologia wnikają w ludzkie ciało, dzięki czemu rodzi się chimera. W inny sposób mierzy się z tym zjawiskiem Ken Feingold - ruchome rzeźby, które często mają twarz samego artysty i są wyposażone w syntetyzatory mowy, wchodzą w interakcję z odbiorcą, rozmawiają z nim. Charakter prac podkreśla ich filozoficzny wymiar. Ken Feingold, jak pisze o nim Erkki Huhtamo, 
„przemierzył wiele krain, realnych i mentalnych oraz pracował z wieloma środkami wyrazu" (Huhtamo 2014: 37). Każdy ze wspomnianych tu twórców porusza się w różnych sferach. Z kolei Bill Vorn ${ }^{25}$, odwołując się do szeroko rozumianej tradycji wykorzystywania automatów i robotów w sztuce, używa - podobnie jak Feingold - języka charakterystycznego dla teatru i określa swoją pracę terminem „sztuka robotyczna” (Vorn 2014). Dopełnieniem ilustracji ludzkiej potrzeby skopiowania lub nawet wymyślenia na nowo jakiejś części nas samych będzie wystawa podejmująca zagadnienia z historii sztuki robotycznej przygotowana przez Jasię Reichardt zatytułowana „Nearly Human”. Jest to - jak mówi autorka opowieść o ludzkiej fantazji przełożonej na język sztuki. Na wystawie zostanie pokazanych ponad siedemdziesiąt prac, począwszy od archiwalnych fotografii, poprzez rysunki i filmy, skończywszy na interaktywnych rzeźbach.

W Europie festiwal „Ars Electronica” jest miejscem, gdzie od ponad dwu dekad można oglądać projekty prezentujące połączenie sztuki z naukowymi dokonaniami. Jest to coroczne wielkie święto wszystkich ludzi twórczych. Festiwal to nie tylko konkurs: to wiele projektów dotykających najbardziej palących spraw współczesnego świata, gdzie kwestie technologii łączą się z ekologią czy problemami społecznymi. Są tu więc pokazywane także modele lub wizualizacje maszyn, robotów, które już mają praktyczne zastosowanie. Nie brakuje też dowcipnych aluzji do naszej tendencji rejestrowania, mierzenia i liczenia wszystkiego ${ }^{26}$.

W Polsce to właśnie Centrum Sztuki Współczesnej Łaźnia podjęło się sukcesywnego prezentowania tego zjawiska. Jest to pionierskie działanie w skali kraju. Współpracujemy z takimi placówkami jak Centrum Nauki Kopernik w Warszawie, Międzyuczelniany Wydział Biotechnologii Uniwersytetu Gdańskiego i Gdańskiego Uniwersytetu Medycznego oraz z szeregiem partnerów za granicą powiązanych z konkretnymi artystami czy wręcz realizacjami. Udało nam się także nakłonić do współpracy taką legendę jak Jasia Reichardt, która w Polsce jest kojarzona głównie z pracą na rzecz upowszechniania twórczości Franciszki i Stefana Themersonów. Na świecie jest postrzegana przede wszystkim jako osoba, która zorganizowała w 1968 roku wspomnianą już pionierską wystawę "Cybernetic Serendipity"27 w londyńskim Instytucie Sztuki Współczesnej (ICA). Jasia Reichardt tematyce sztuki i nauki poświęciła wiele uwagi w całej swojej pracy. Fakt, że wychowywała się w domu Thermersonów, miał ogromne znaczenie dla jej rozwoju intelektualnego, bo tam właśnie podczas spotkań w Common Room, działającym w latach 1957-1959 przy Gaberbocchus Press, zetknęła się z wyznawcami wspólnej filozofii sztuki i nauki, o formule jedynej w swoim rodzaju i wywrotowej jak na owe czasy w Wielkiej Brytanii, a nawet - nie obawiam się tego powiedzieć - na świecie; i nie zmienia tego fakt, że wówczas także

${ }^{25}$ Więcej na ten temat na stronie http://artandsciencemeeting.pl/ oraz www.laznia.pl, a także w publikacji towarzyszącej gdańskiej wystawie (zob. Kluszczyński et al. 2014).

${ }^{26}$ Znowu tu przywołam Christę Sommerer i Laurenta Mignonneau z prezentacją na http:// www.interface.ufg.ac.at/christa-laurent/WORKS/FRAMES/FrameSet.html [dostęp: 30.08.2014] czy powstałą w ramach projektu „Climate Whirl Project” przygotowanego przez Wydział Nauk Leśnych i Wydział Fizyki Uniwersytetu w Helsinkach oraz Simosol Oy and Capsula pracę Teacup Tools Agnes Meyer-Brandis, której rozwój możemy śledzić na http://www.ffur.de/tea [dostęp: 30.10.2014]).

${ }^{27}$ Więcej na ten temat na http://cyberneticserendipity.net/ oraz https://www.ica.org.uk/whatson/cybernetic-serendipity-documentation [dostęp: 30.08.2014]. 
nowojorska MoMa pokazała „The Machine as Seen the End of the Mechanical Age $^{\prime 28}$, bo dziś obydwie wystawy uważane są za legendarne.

\section{Znaczenie prowadzonych działań z perspektywy edukacji poprzez sztukę}

Sprawa edukowania poprzez sztukę jest wciąż dyskutowana i odkrywana na nowo. Kilka dekad temu polskie muzea i galerie proponowały co najwyżej oprowadzanie po wystawie. Jednakże coraz mocniej dostrzegalne poczucie konfuzji odbiorcy w zetknięciu ze sztuką współczesną stało się przyczynkiem do organizacji szeregu konferencji, warsztatów i lekcji wprowadzających w zagadnienia $\mathrm{z}$ zakresu historii sztuki, również $\mathrm{w}$ zakresie tej najnowszej. Obecnie poświęca się wiele uwagi roli sztuki w edukacji, jak też sprawie samej sztuki jako zjawiska kulturowego i społecznego. Ale jest to wciąż mowa o narzędziach, jakimi chcemy posługiwać się w nawiązywaniu kontaktu z publicznością czy uczestnikami warsztatów. Wiele mówi się o roli instytucji kultury definiowanej przez konkretną osobę.

Zasadom odnoszącym się do personalistycznej koncepcji zarządzania instytucją towarzyszą i wspierają ich realizację tzw. zasady przywództwa służebnego, wprowadzone do dyskursu naukowego przez Roberta Greenleafa. [...] Prawdziwego przywódcę, organizatora życia społecznego, zarządzającego instytucją charakteryzuje postawa, której atrybutem jest potrzeba służenia innym $\mathrm{w}$ dochodzeniu do ich doskonałości poprzez towarzyszenie im lub udzielanie pomocy $\mathrm{w}$ tym procesie (Skutnik 2014: 36).

W świecie rynkowym bowiem indywidualizm, wyrazistość zamykana w określeniu "marka" decyduje o widoczności, a więc zainteresowaniu jej aktywnością potencjalnej publiczności.

Warto zdefiniować cele takiej formy docierania do uczestników różnego rodzaju artystycznych pokazów w szczególności tych, gdzie pojawiają się maszyny czy wręcz są eksponowane obiekty powstałe na skutek procesów laboratoryjnych. Pojawia się bowiem pytanie o przyczynę tej formy prezentacji. Gdy wyprowadzamy eksponaty z laboratoriów, dbamy o jak najszerszą informację związaną z każdą taką pracą, widz jednak ma prawo zapytać, dlaczego autor zdecydował się na ten rodzaj opowieści? Jakie pytania chciał postawić? Prawdziwy rebus do rozwiązania.

Wiele lat temu dostałam prezent: zastaw fotografii struktur witamin wykonanych przy pomocy elektronowego mikroskopu. Kolorowe, abstrakcyjne obrazy odkryte dzięki czułemu urządzeniu zrobiły na mnie ogromne wrażenie. Damien Hirst, mówiąc o swej fascynacji lekami, podkreśla potrzebę kontrastowania w sztuce. Człowiek potrzebuje bodźców, aby pojąć to, co dzieje się wokół niego. Przekaz jest skuteczny, gdy informacja porusza.

Warto pamiętać, że „Po pierwsze, każdy, kto poważnie pragnie zostać filozofem, musi raz w swoim życiu cofnąć się do siebie samego i podjąć próbę zdobycia się

\footnotetext{
${ }^{28}$ Więcej na ten temat w archiwum MoMa: https://www.moma.org/momaorg/shared/pdfs/docs/ press_archives/4149/releases/MOMA_1968_July-December_0081.pdf?2010 [dostęp: 30.08.2014].
} 
w sobie samym na obalenie wszystkich obowiązujących dlań dotąd nauk i zbudowania ich na nowo. Filozofia - mądrość (sagesse) - jest absolutnie osobistą sprawą filozofującego", jak powiedział Edmund Husserl (za: Bożeński 2000: 11). W edukowaniu jest ważny skuteczny przekaz. Każdy, kto podejmuje się nauczania, mierzy się z samym sobą. Fantazja ludzka i sztuka pozwalają oprawić wiedzę w emocje, nadać jej kształt i kolor, uczynić przystępną. I taka jest rola współczesnej galerii czy muzeum. Jak bowiem zostało powiedziane pewien czas temu podczas poznańskiej debaty, „kultura nie jest dla wszystkich, ale - jest dla każdego. I ma za zadanie każdemu z nas - a nie tylko «kompetentnym kulturalnie» wybrańcom - stwarzać szansę na spełnienie naszego osobistego potencjału" ${ }^{29}$. Najważniejsze, że ta aktualna myśl opisuje rolę sztuki współczesnej zarówno z perspektywy twórcy, jak i publiczności.

\section{Literatura:}

Bożeński W., 2000, Pęknięty witraż. Człowiek w epoce globalizmu, Gdańsk: Wydawnictwo Andromeda.

Charzyńska J., 2011, Sztuka i nauka czy może sztuka plus nauka?, http://artandsciencemeeting. $\mathrm{pl} / ? \mathrm{p}=72$ [dostęp: 3.08.2013].

Czeglédy-Nagi N., 2011, The pleasure of light. György Kepes, Frank J. Malina na skrzyżowaniu nauki i sztuki, tłum. K. Koriat, Z. Ziemann, Warszawa-Gdańsk: Wydawnictwo Narodowe Centrum Kultury i Centrum Sztuki Współczesnej Łaźnia.

Fromm E., 2009, Mieć czy być? Poznań: Dom Wydawniczy Rebis.

Huhtamo E., 2014, Z ust lalki, niejasno [w:] Ken Feingold. Figury mowy, red. R.W. Kluszczyński et al., Gdańsk: Wydawnictwo Centrum Sztuki Współczesnej Łaźnia.

Kluszczyński R.W., 2011a, http://artandsciencemeeting.pl/?page_id=57 [dostęp: 3.08.2013].

Kluszczyński R.W. (red.), 2011b, W stronę trzeciej kultury. Koegzystencja sztuki, nauki i technologii, tłum. M. Grabarczyk, K. Koriat, Gdańsk: Wydawnictwo Narodowe Centrum Kultury i Centrum Sztuki Współczesnej Łaźnia.

Kluszczyński R.W., 2011c, The Performing Data. Monika Fleischmann + Wolfgang Strauss, Warszawa-Gdańsk: Wydawnictwo Narodowe Centrum Kultury i Centrum Sztuki Współczesnej Łaźnia.

Kluszczyński R.W. et al. (red.), 2014, Sztuka i kultura robotów. Bill Vorn i jego Histeryczne Maszyny, Gdańsk: Wyd. Centrum Sztuki Współczesnej Łaźnia.

Koschany R., Skórzyńska A. (red.), 2014, Edukacja kulturowa. Podręcznik, Poznań: Wydawnictwo Centrum Kultury Zamek, http://www.wpek.pl/pi/98258_1.pdf [dostęp: 30.08.2014].

Reichardt J., 2015, O czym jest ta wystawa [w:] Nearly Human, Gdańsk: Wydawnictwo Centrum Sztuki Współczesnej Łaźnia.

Skutnik J., 2014, Uczestnictwo kulturalne z perspektywy personalistycznej-analiza wybranych obszarów działalności instytucji kultury [w:] Edukacja kulturowa. Podręcznik...

Vorn B., 2014, Kataraktyczny teatr sztuki robotycznej [w:] Sztuka i kultura robotów...

Żabicki P., 2007, Technologiczna codzienność. Internet - Bank - Telewizja, Warszawa: Wydawnictwo Trio.

${ }^{29}$ Konferencja „Praktyki i metody edukacji kulturalnej”, która odbyła się w Centrum Kultury Zamek w Poznaniu w 2013 roku i została podsumowana w publikacji Edukacja kulturowa. Podręcznik. (Koschany, Skórzyńska 2014). 


\section{Summary \\ Chimera and Virtual Vetwork, or a Contribution to the New World Order (Art and Science Relationships on "Art + Science Meeting")}

The "Art + Science Meeting" project presents art and science through an expanded exhibition, workshop, publication, meeting and debate program as two different perspectives of the same reality. The interdisciplinary open to discussion character of the project gives a possibility to present the achievements of world's most outstanding artists who create in the hybrid area of science and technology: art and biotechnology, genetics, computer science, nanotechnology, research into artificial life and artificial intelligence... It also allows a wider look on the contemporary civilization for which science and technology are progress conditions but still remain opaque.

\section{Keywords}

art, science, technologies, biotechnologies, machines

\section{Słowa kluczowe}

sztuka, nauka, technologie, biotechnologie, maszyny 